\title{
1. Authority under IHL: What are we looking for?
}

The question of whether IHL is an exclusively restrictive regime, or whether it is both permissive and restrictive, is not a recent one. The writings of Grotius, Vattel and others contained elements related to the nature of the laws of war. Francisco de Vitoria had already written in 1532 on the 'right to kill' and determined that, although it is generally not permitted to kill innocents, it may be permitted to kill innocents incidentally during a just war. ${ }^{1}$ Later, Grotius developed the notion of licencia, or permission/lawfulness, ${ }^{2}$ as intrinsically linked to necessity. ${ }^{3}$ Grotius also made the distinction between being permitted because desirable, and being permitted because of the absence of liability attached to the act. ${ }^{4}$ Similarly, according to Vattel, only the means necessary to achieve an end are permitted. ${ }^{5}$ The same idea is found in Rousseau's Du Contrat Social, in which he wrote that 'la guerre ne donne aucun droit qui ne soit nécessaire à sa fin' ${ }^{6}$ Today, the discussion remains open. Some reject the idea that IHL would "“authorize" states to engage in conduct otherwise prohibited', viewing it

1 Francisco de Vitoria, De jure belli, 52, quoted in Jean-Mathieu Mattéi, Histoire $d u$ droit de la guerre (1700-1819): introduction à l'histoire du droit international (Aix-en-Provence: Presses universitaires d'Aix-Marseille, 2006), Vol. I, 416.

2 Hugo Grotius, De jure belli ac pacis, 3 Books (London: D. Brown; T. Ward; and W. Meares, 1715), Book III, Chapter IV, 61 ff. See also ibid., Book III, Chapter I, Section II, 1-2.

3 Ibid., Book III, Chapter I, Section II, 2. See further Mattéi, Histoire du droit de la guerre (n 1), 422 ff; Alfred Dufour, Peter Haggenmacher and Jiri Toman (eds), Grotius et l'ordre juridique international (Lausanne: Payot, 1985). Others consider that Grotius' writings imply that the laws of war are restrictive. See e.g. Austin Sarat, Lawrence Douglas and Martha Merrill Umphrey, Law and War (Stanford: Stanford University Press, 2014), 12.

4 See Grotius, De jure belli ac pacis (n 2), Book III, Chapter IV, 61, 'On the right of killing enemies in a solemn war, allowed by the Law of Nations'. See also on this subject Mattéi, Histoire du droit de la guerre (n 1), 422-423.

5 Emer de Vattel, Le Droit des gens ou principes de la loi naturelle appliqués à la conduite et aux affaires des nations et des souverains (Paris: Janet et Cotelle, 1820), Book III, Chapter VIII, Section 137, 589. See also Mattéi, Histoire du droit de la guerre (n 1), 245.

${ }_{6}$ Jean-Jacques Rousseau, Du contrat social (1762), Book I, Chapter IV (Translation: War does not give any right that is not necessary to its end). 
instead as 'intended to respond to normative "underapplication", meaning the lack of any applicable law, by establishing certain humanitarian protections'.?

A variety of synonyms has been used to phrase the question of the nature of IHL: does IHL provide a 'legal basis', ${ }^{8}$ a 'right', ${ }^{9}$ an 'authority', ${ }^{10}$ an 'authorization', ${ }^{11}$ a 'power', ${ }^{12}$ a 'permission', ${ }^{13}$ a 'license' ${ }^{14}$ to resort to certain conducts during armed conflict? All these terms refer to the existence of permissive rules within IHL. But is saying that 'IHL provides a legal basis' really the same as saying that 'it contains a permission' or even that 'it contains a right'? Although ordinarily used as synonyms, these terms may entail different degrees of permissiveness, the nuances of which should not be lost to a legal mind. So, what exactly are we looking for?

In legal theory, looking at permissions within a legal system means looking at the deontic mode of the rules contained in that system. By 'deontic', we refer to the definition proposed by Georg H. von Wright, according to which deontic modes include "concepts such as the obligatory (that which we ought to do), the permitted (that which we are allowed to do), and the forbidden (that which

7 Matthias Lippold, 'Between Humanization and Humanitarization? Detention in Armed Conflicts and the European Convention on Human Rights', Zeitchrift für ausländisches öffentliches Recht und Völkerrecht, Vol. 76 (2016), 64.

8 See e.g. Els Debuf, Captured in War: Lawful Internment in Armed Conflict (Paris: Pedone, 2012).

9 See e.g. Sean Aughey and Aurel Sari, 'Targeting and Detention in Non-International Armed Conflict: Serdar Mohammed and the Limits of Human Rights Convergence', International Law Studies, Vol. 91 (2015), 60-118; Peter Rowe, 'Is There a Right to Detain Civilians by Foreign Armed Forces During a Non-International Armed Conflict?', International and Comparative Law Quarterly, Vol. 61, No. 03 (2012), 697-711.

10 See e.g. Robert E. Barnsby, 'Yes, We Can: The Authority to Detain as Customary International Law', Military Law Review, Vol. 202 (2009), 53-90; Gabor Rona, 'Is There a Way Out of the Non-International Armed Conflict Detention Dilemma?' International Law Studies, Vol. 91 (2015), 32-59.

11 See e.g. Curtis A. Bradley and Jack L. Goldsmith, 'Congressional Authorization and the War on Terrorism', Harvard Law Review, Vol. 118, No. 7 (2005), 2047-2133; Ryan Goodman, 'Authorization versus Regulation of Detention in Non-International Armed Conflicts', International Law Studies, Vol. 91 (2015), 155-170.

12 See e.g. Ryan Goodman, 'The Power to Kill or Capture Enemy Combatants', European Journal of International Law, Vol. 24, No. 3 (2013), 819-853.

${ }_{13}$ See e.g. Katja Schöberl and Linus Mührel, 'Sunken Vessel or Blooming Flower? Lotus, Permissions and Restrictions within International Humanitarian Law', in Björnstjern Baade, Linus Mührel and Anton O. Petrov (eds), International Humanitarian Law in Areas of Limited Statehood: Adaptable and Legitimate or Rigid and Unreasonable? (Baden-Baden: Nomos, 2018), 59-79.

14 See e.g. Tom Ruys, 'License to Kill? State-Sponsored Assassination under International Law', Military Law and Law of War Review, Vol. 44, Nos. 1-2 (2005), $13-49$. 
we must not do)'. ${ }^{15}$ These may also be referred to as prescription (obligation), proscription (prohibition) and permission. Applied to our field, it is clear that IHL contains prescriptions and prohibitions. What is less clear is the existence within IHL of rules the deontic mode of which is permission. ${ }^{16}$

\section{STRONG AND WEAK PERMISSIONS}

In his seminal work Norm and Action, von Wright elaborates the distinction between permissions arising out of the absence of rules, called weak permissions, and permissions based on the existence of a valid enabling rule, called strong permissions. ${ }^{17}$ The distinction between the two kinds of permission means that an act is 'strongly permitted only if its being permitted is entailed by a norm', while '[i]t is permitted in the weak sense if the permission is not entailed by any existing norm but is simply a consequence of there being no norms prohibiting the performance of the action'. ${ }^{18}$ Applied to international law, the distinction is between " freedom of action" corresponding to absolute sovereignty, ie sovereignty not limited by any legal rule whatsoever', and 'freedom within the law'. ${ }^{19}$

Logicians, philosophers and legal theorists have questioned whether the distinction between weak permissions and strong permissions is relevant in

\footnotetext{
15 Georg Henrik von Wright, 'Deontic Logic', Mind, New Series, Vol. 60, No. 237 (January 1951), 1.

16 The question of whether there is such a thing as an independent deontic mode of permission, and of whether it can be reduced to a mere sub-category of the deontic mode of prohibition (so that permission $=$ non-prohibition) is one of the most debated subjects within legal theory. As this book attempts to determine whether IHL contains permission, we take the position that there is an independent deontic mode of permission. For detail on this position, see e.g. Manuel Atienza and J. Ruiz Manero, A Theory of Legal Sentences (Dordrecht: Kluwers, 1998), 90.

17 Georg Henrik von Wright, Norm and Action: A Logical Enquiry (London: Routledge and Kegan Paul, 1963), 86.

18 Joseph Raz, Practical Reason and Norms (Oxford: Oxford University Press, 1999), 85. Other scholars have used varying terms to refer to this distinction, however to the same effect. See e.g. Carlos E. Alchurrón and Eugenio Bulygin, Normative Systems (Vienna/New York: Springer-Verlag, 1971), 119-125; Stephen Munzer, 'Validity and Legal Conflicts', Yale Law Journal, Vol. 82, No. 6 (1973), 1141-1142; Raz, Practical Reasons and Norms (above), 85 ff; Ige F. Dekker and Harry H. G. Post, On the Foundations and Sources of International Law (The Hague: TMC Asser Press, 2003), 18; Julius Stone, 'Non Liquet and the International Judicial Function', in Chaïm Perelman, Le Problème des Lacunes en Droit (Brussels: Bruylant, 1968), 309; Ulrich Fastenrath, Lücken im Völkerrecht (Berlin: Duncker \& Humblot, 1991), 213.

19 Carlo Focarelli, International Law as Social Construct: The Struggle for Global Justice (Oxford: Oxford University Press, 2012), 281.
} 
itself. ${ }^{20}$ However, several reasons show that it is, at least for the purposes of our study. First, as opposed to weak permissions, strong permissions have a normative force, or at least a greater normative force. ${ }^{21}$ They indicate that the legal system has taken a position on the deontic character of the action. This is precisely what we are looking for: signs that IHL voluntarily permits certain conducts.

Second, and in direct relation to the first point, the question of the existence of permissions within IHL is made relevant in practice by the requirement under IHRL that certain conducts have a legal basis before they can be resorted to. Such requirement obviously implies the existence of a valid permissive rule, for the mere absence of a prohibition cannot amount to a legal basis. Therefore, at least for our study, IHRL has made relevant the distinction between weak and strong permissions, by rendering necessary the existence of legal bases and hence of power-conferring permissive rules (i.e. strong permissions).

Lastly, we could add here a teleological element of answer: if weak permissions are logically possible, then we need to maintain the distinction, otherwise the statement 'this behaviour is permitted' is ambiguous. The statement can indeed have two different meanings. First, it can 'mean that this behaviour is not the object of any norm, especially, that this behaviour is neither forbidden nor commanded, i.e. that neither this behaviour nor its omission is commanded by a norm' ${ }^{22}$ In such a case, the character of 'being permitted' has a purely negative signification. Second, by opposition, the same statement may also refer to the existence of a valid, enabling norm explicitly permitting the behaviour. This is important for us: when States or other actors on the international scene say that a conduct is permitted, it may not necessarily reflect the belief in the existence of a strong permission. It may be the result of the absence of a rule prohibiting such conduct.

Therefore, we shall proceed on the basis that strong permissions do exist in law and that they have a normative value distinct from that of (an absence of) prohibitions or prescriptions. Looking for permissive rules under IHL therefore means looking for strong permissions.

20 See e.g. Atienza and Manero, A Theory of Legal Sentences (n 16), 92 ff; Dekker and Post, Foundations and Sources (n 18), 19-20; Raz, Practical Reasons and Norms (n 18), 87.

${ }_{21}$ See e.g. Raz, Practical Reasons and Norms (n 18), 87; von Wright, Norm and Action (n 17), 85-89.

22 Hans Kelsen, General Theory of Norms, trans. by Michael Hartney (Oxford: Oxford University Press, 1991), 98. 


\section{NATURE AND FORM OF STRONG PERMISSIONS}

While any type of strong permission would be sufficient in order to affirm that a State is permitted to do something under international law, this may not be sufficient to meet the requirements posed by IHRL. As will be extensively discussed in Parts II and III, ${ }^{23}$ at least for internment and targeting of persons, IHRL seems to require the existence of a legal basis authorizing the restriction respectively of the right to liberty or the right to life. The question can thus be phrased in the following terms: does IHL provide the legal basis required by IHRL, at least for conducts carried out in relation to an armed conflict? Three possibilities exist. First, IHL contains such legal basis. Second, IHL contains a degree of permission that nevertheless does not amount to an appropriate legal basis. Third, IHL only contains weak permissions, i.e. it simply does not prohibit the conduct. Each of these possibilities will have an impact on the interaction between the two regimes.

\subsection{Strong Permissions}

Legal theory does not attach any specific form to the notion of strong permission. The latter may take several forms, ranging from expressly worded permissions to more implicit permissions. The former case is rather easy to spot. When explicitly worded, strong permissions will usually contain a positive mark denoting the permission, e.g. an adjective, either predicative ('X-type of conduct is permitted') or attributive ('the authorized conducts include ...'), a modal verb marking the permission ('one may do X'), or any other permissive noun or verb (for instance, 'the law authorizes X', 'it is permitted to do X', etc.). By contrast, implicit strong permissions may be more difficult to spot. And yet, legal theory acknowledges that most strong permissions take the form of derogations or restrictions, ${ }^{24}$ i.e. not explicit permissions. ${ }^{25}$

23 See Chapter 9 on the right to liberty and Chapter 12 the right to life, at pages 213 and 300 respectively.

24 Derogations are here understood as rules repelling, or creating exceptions to, other pre-existing or coexisting prohibitive or prescriptive rules. Restrictions consist in rules that limit the applicability of other pre-existing or coexisting rules. See e.g. Munzer, 'Validity and Legal Conflict' (n 18), 1142; Kelsen, General Theory of Norms (n 22), 98 .

${ }_{25}$ We should note here that we do not include in this category the cases where an act or an object is excluded from the scope of application of the rule. For instance, weapons treaties that exclude certain sub-categories of weapons from their scope of application should not be considered as strongly permitting such excluded sub-categories. For a discussion of this, see Chapter 4, Section 5, at page 55. 
For instance, according to Kelsen, in a legal system containing a rule that 'prohibits killing human beings (i.e. commands refraining from killing)', the 'norm [that] restricts the validity of this norm by making an exception for cases of self-defence' amounts to a strong permission. ${ }^{26}$ Kelsen bases his argument on the fact that derogations intend to ' $m a k[e]$ something free, unlike negative permitting, ${ }^{27}$ when a conduct is free without having been made free by law. In that sense, we agree with Kelsen that derogations and restrictions are strong permissions, though indirect ones, resulting from the fact that the prohibition has been repealed or restricted. ${ }^{28}$ Remembering von Wright's definition: strong permissions indeed exist 'if the authority has considered [the] normative status [of an act] and decided to permit it' ${ }^{29}$

We shall note here that a strong permission may be raised to the degree of right, which, however, corresponds to a higher degree of permission. The notion of 'right' indeed comes with a corollary obligation: the existence of a right of one person (or of one State) is attached to the existence of an obligation for someone else (or for other States) to respect such right. ${ }^{30}$ The initial permission is there 'combined with a prohibition to hinder or prevent the holder of the permission from doing the permitted thing'. ${ }^{31}$ Applied to international law, this means that '[o]nce the rule is established as existing, the permission contained therein may limit the sovereignty of other states if and to the extent that the rule entails a right whose counterpart is a prohibition imposed on other states not to encroach it' ${ }^{32}$ For instance, a right of passage entails not only the legal basis for one State to have its ships pass through the territorial seas of other States, but also the obligation for the other States to allow such passage, or the prohibition on hindering such passage. The notion of 'right' has sometimes been referred to as de jure freedom, where the performance of an act is 'protected by the law through a correlative prohibition imposed on transgressors'. 33

26 Kelsen, General Theory of Norms (n 22), 98.

27 Ibid., 99.

28 Ibid. See also Alchurrón and Bulygin, Normative Systems (n 18), 368; Dekker and Post, Foundations and Sources (n 20), 20; Munzer, 'Validity and Legal Conflict' (n 18), 1142.

29 von Wright, Norm and Action (n 17), 86.

30 Robert Kolb, Advanced Introduction To International Humanitarian Law (Cheltenham: Edward Elgar Publishing Limited, 2015), 18. See also Hans Kelsen, Principles of International Law, 2nd ed. revised and edited by Robert W. Tucker (New York/Chicago/San Francisco/Toronto/London: Holt, Rinehart and Winston, Inc., 1966), 7.

31 von Wright, Norm and Action (n 17), 89.

32 Focarelli, International Law as Social Construct (n 19), 281.

33 Ibid., 280. 
It should be noted that some authors, such as Kelsen, seem to reject the distinction between what we consider a simple strong permission and a right. ${ }^{34}$ However, we believe that the logic of IHL requires distinguishing between the two notions. The logic of IHL is such that it does not grant many 'rights' to the parties to an armed conflict, for they would imply an obligation for other parties to accept the behaviour concerned. ${ }^{35}$ For instance, a 'right' to intern prisoners of war would imply an obligation on the part of the enemy party not to hinder or to put an end to the internment of its captured members. There is of course no such obligation under IHL, and a party that launched an operation to free members of its armed forces detained by the enemy would not be in violation of IHL, provided that the rules on conduct of hostilities were respected. ${ }^{36}$ Under IHL indeed, permissions are not necessarily accompanied by a corresponding obligation on other States not to interfere with the permitted conduct. No State would agree to impose on itself the obligation to remain passive towards the acts of other States, to suffer the consequences without reacting, even when such acts are legally permitted. ${ }^{37}$ As a consequence, under IHL, what are sometimes called rights are 'rights of a particular nature' ${ }^{38}$ Only neutral States have an obligation to tolerate them; belligerents by contrast enjoy 'identical and equal powers', the confrontation of which 'constitutes the essence of belligerency' ${ }^{39}$

To summarize, the strong nature of a permission is mostly defined by its substance. Regardless of the form taken by the rule, what matters is that the legal system has attached a permissive normative value to a given act. As a consequence, derogations and restrictions built in the prescriptive or prohibitive rules of IHL will amount to strong permissions. In such cases we will be able to conclude that IHL 'permits' in the strong sense. By contrast, although

34 Hans Kelsen, General Theory of Law and State, trans. by Anders Wedberg (Clark: The Lawbook Exchange, 2007), 76-77.

35 This may sound counter-intuitive at first, given the high number of scholarly works or official statements and documents that have referred to 'the rights of belligerents' under IHL. See as early as during the Brussels Conference in 1874: Actes de la conférence de Bruxelles de 1874 sur le projet d'une convention internationale concernant la guerre : protocoles des séances plénières : protocoles de la commission déléguée par la conférence : annexes / Conférence intergouvernementale [Ministère des affaires étrangères] (Paris: Wittersheim, 1874), 28 and 30.

36 See also Giorgio Balladore Pallieri, La guerra (Padua: CEDAM, 1935), 163-164 for similar examples.

37 See e.g. Robert Kolb, Theory of International Law (Oxford/Portland: Hart Publishing, 2016), 227.

38 Henri Meyrowitz, Le principe de l'égalité des belligérants devant le droit de la guerre (Paris: Pedone, 1970), 112.

39 Ibid. 
we may find references to the 'rights of belligerents', the notion of 'right' entails a higher degree of strength and should only be used when a corollary prohibition exists to hinder the performance of the act. By extension, this study will consequently refer to 'permission', 'power', or 'competence', while avoiding the term 'right', except when meeting the definition just presented.

\subsection{Legal Basis}

In the context of this study, the notion of legal basis is intrinsically linked to the principle of legality. The latter is first a formal requirement: it 'dictates that the enjoyment or exercise of individual rights and freedoms cannot be restricted except by law'. ${ }^{40}$ This means that a valid legal basis must be provided that authorizes the restriction placed on certain rights and freedoms. A legal basis shall then be understood as the concrete, material manifestation within law of an entitlement to perform an act, or entitlement not to perform an act. Generally speaking, a legal basis will provide the authority to perform (or to not perform) an act; in that sense 'legal basis' may be equated with 'legal entitlement', 'authority' or 'authorization'.

The principle of legality also contains a material/substantive aspect: each right or freedom may be restricted only for legitimate reasons, or on 'grounds that reflect a legitimate purpose'. ${ }^{41}$ This material aspect will differ depending on the right protected. For instance, the law governing lawful restrictions to the right to liberty will not be the same as that governing the lawful restrictions to the right to life.

Accordingly, the requirement of a legal basis includes both a formal requirement and a material/substantive one. It is therefore impossible to simply equate the notion of strong permission to that of legal basis, for strong permissions may lack one or the other (or both) of the above-mentioned requirements. In some cases, strong permissions lack the formal aspect because they are not articulated in a manner that clearly provides a legal entitlement. In other cases, a strong permission may not provide the material elements required to restrict a certain right (although it may still meet the formal requirement). This means that, if all legal bases are necessarily strong permissions, not all strong permissions are legal bases.

If a legal basis is found within IHL about a specific act, we will be able to say that IHL not only attaches a normative value to the performance of the act, but also formally authorizes it. The following terms become synonymous:

\footnotetext{
40 Debuf, Captured in War (n 8), 42.

41 Ibid., 41
} 
performing a specific act is 'authorized', 'permitted' (in the strong sense), has 'a legal basis'.

\subsection{Regulations as Weak Permissions}

We should here consider cases where IHL is limited to not prohibiting a specific conduct, while still regulating it. Whether the act is performed or not is indifferent from the perspective of IHL; the latter only considers the factual possibility that the act will be performed, and contains regulations as to how it may be performed. We shall call this regulatory freedom.

Does the mere regulation of a certain act presuppose the existence of a strong permission? Or does it remain a weak permission? This question is a necessary one, for several authors have used the existence of regulations as evidence that IHL would authorize such regulated conducts. ${ }^{42}$ To answer it, we can simply take two examples close to our field of study. First, the separation between jus ad bellum and jus in bello means that the regulation of armed conflict by IHL obviously cannot be considered as permitting armed conflict. The latter aspect is outside of the realm of IHL and is determined by jus ad bellum. Second, most would agree that IHL is normatively neutral regarding the legality of occupation. Neither authorizing nor prohibiting it, IHL only prescribes specific rules in case occupation occurs. In the end, it means that regulations without parallel strong permissions merely imply the existence of weak permissions and do not create strong ones. Under IHL, the mere existence of regulations should not be understood as creating strong permissions. It becomes incorrect to say that 'IHL authorizes', 'IHL contains a legal basis', or even 'IHL permits' when only regulations without permission - i.e. a weak permission - exist. One can nevertheless say that 'IHL does not prohibit' or that a given conduct is 'lawful' under IHL (provided it complies with the applicable rules).

42 See e.g. Aughey and Sari, 'Targeting and Detention' (n 9), 95-97; Barnsby, 'Yes, We Can' (n 10), 78. 